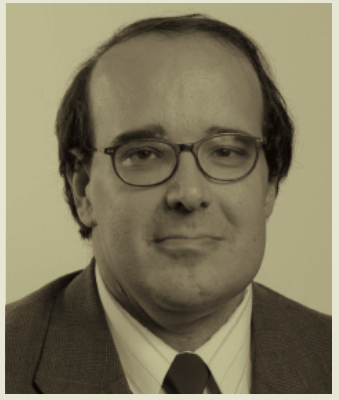

\title{
COMO MEDIR A QUALIDADE DO ATENDIMENTO?
}

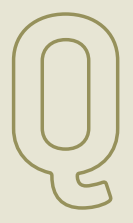

ualquer administrador que se preze, seja em uma pequena, média ou grande organização, tem como balizador de suas atividades alcançar determinadas metas quantitativas. Aumentar as vendas e o faturamento, conquistar market share e reduzir os custos de operação estão entre os objetivos mais almejados.

Ao mesmo tempo, observando o discurso empregado nas ações de comunicação e promoção das empresas, nota-se que a maioria delas afirma ter como prioridade a qualidade do atendimento e a satisfação dos clientes. Nesse cenário, cabe refletir: será que, de fato, as métricas adotadas pelas corporações dão a devida atenção aos clientes? Será que os gestores realmente têm consciência dos ganhos decorrentes de um bom atendimento?

Avaliar o desempenho de uma organização baseando-se somente no incremento nas vendas ou no ticket médio dos clientes é bastante fácil. Difícil é medir o impacto que um bom ou mau atendimento pode exercer nas decisões de compra futura dos clientes. Por outro lado, considerando os custos envolvidos - financeiros, operacionais, de tempo e de infraestrutura -, reter um cliente é sem dúvida mais econômico e vantajoso do que conquistar um novo. Também nunca é demais recordar que o consumidor satisfeito pode até aceitar pagar um pouco mais por um dado produto ou serviço. Sem mencionar a divulgação, a custo zero, que ele fará sobre a empresa a seus amigos e conhecidos, lembrando que a indicação de um cliente vale mais do que qualquer propaganda.

Nesse contexto, é fundamental debater melhor as métricas de qualidade do atendimento. Como monitorar as operações e os processos envolvidos? Quais indicadores devem ser utilizados?
Na área de Call Center, por exemplo, indicadores de produtividade costumam ser mal utilizados e confundidos com indicadores de qualidade. Vejamos o caso clássico do TMA, ou tempo médio de atendimento. Gestores costumam considerar um tempo ideal de duração da ligação telefônica - digamos, de até dois minutos - para classificar um "bom" atendimento telefônico. Imaginemos, porém, que um dado cliente ligue apenas para obter uma informação simples, como um número de telefone ou endereço: seu atendimento será bem avaliado, pois durará apenas o tempo necessário para obter a informação no banco de dados. Por outro lado, quando um cliente tiver algum problema complexo, que demande mais do que uma simples consulta, a adoção do TMA como critério de qualidade será contraproducente. Sabendo que o caso levará mais tempo do que o ideal, os atendentes se verão incentivados a derrubar a ligação para não comprometer seu tempo médio.

Assim, cabe perguntar por que os gestores não adotam, por exemplo, a taxa de resolutividade como parâmetro de qualidade. Tal indicador computaria o número de ligações, independentemente de sua duração, até que o cliente tivesse a sua demanda solucionada. Quanto mais próximo de 1 - ou seja, uma única ligação para sanar o problema - mais bem avaliado seria o atendimento. Obviamente, há situações que demandam mais interações, e, a fim de contemplá-las, o parâmetro poderia ser sofisticado, por exemplo, levando em conta o número de interações ativas da empresa - não para vender ou promover algo, mas para buscar alternativas de solução para o problema.

Um indicador como esse seria certamente superior ao TMA para medir a qualidade do atendimento. Claro que a questão é complexa e ainda há muito a ser discutido, mas vale a reflexão! 